\section{Tuberculosis control: managers' work in question}

\section{Abstract}

Introduction: Tuberculosis is a re-emerging disease in developed countries, and keeps high prevalence in developing nations. Currently still remains as a public health problem unsolved and a challenge to be faced.

Objective: Evaluating the difficulties and ease in compliance with Supervised Treatment for Tuberculosis from the perspective of managers who act in the control of tuberculosis in priority cities in Paraiba by the National Program for Tuberculosis Control.

Method: An evaluative study of qualitative approach, whose sample was composed of six managers. Data were collected through interviews with semi-structured instrument; and processed by the analysis technique of speech of Bardin.

Results: Management, lack of working condition, the disengagement of patients to adhere to supervised treatment and the resistance of professionals to put into practice the supervised treatment have been the main difficulties encountered.

Conclusion: Being the most significant difficulties than the ease, tuberculosis control actions are limited and do not produce satisfactory results. There was perceived need to strengthen management and involvement of the subjects to fight the disease.
Elicarlos Marques Nunes', Tânia Maria Ribeiro Monteiro de Figueiredo², Maria Aparecida Alves Cardoso $^{3}$, Fernanda Darline Tavares de Luna 4 , Maria do Carmo Andrade Duarte de Farias ${ }^{5}$, Mayrla Lima Pinto ${ }^{6}$, Anne Milane Formiga Bezerra7, Kévia Katiúcia Santos Bezerra5 ${ }^{5}$, Mirelly Aristoteles Pereira7, Roberta Amador Abreu7, Wilma Kátia Trigueiro Bezerra ${ }^{8}$, Ariane Rocha Gonçalves7

1 Teaching at the Department of Nursing of the Integrated Faculty of Patos, Patos, PB, Brazil.

2 Teaching at the Postgraduate Program in Public Health at the State University of Paraiba, Campina Grande, PB, Brazil.

3 Teaching at the Department of Pharmacy of the State University of Paraiba - Campina Grande, PB, Brazil.

4 Care Nurse of the Family Health Strategy Guarabira/PB/Brazil.

5 Academic Unit of Life Sciences, Teacher training center, Federal University of Campina Grande. Cajazeiras, PB, Brazil.

6 Master in Public Health at the State University of Paraiba - Campina Grande, PB, Brazil.

7 Nurse in a Mobile Emergency Service, MSU, Sousa, PB, Brazil.

8 Nurse in a Mobile Emergency Service, MSU Paulista, PB, Brazil.

Contact information:

Maria do Carmo Andrade Duarte de Farias. Academic Unit of Life Sciences, Teacher training center, Federal University of Campina Grande

” carmo.andrade@ufcg.edu.br Keywords Health Services; Organization; Management; Tuberculosis. 


\section{Introduction}

Tuberculosis (TB), a disease classified as infectious and contagious, throughout the twentieth century was characterized as a public health problem worldwide and in Brazil, and became known as the neglected calamity of nations; even in the XXI century remains a problem unsolved and it is great challenge to be faced ${ }^{[1-2]}$.

It is estimated that one third of the world population is infected with Mycobacterium tuberculosis. In 2010 there was recorded in the world 8.8 million incident cases, 1.1 million TB deaths, 350.000 deaths of people with co-infection (TB/Acquired Immunodeficiency Syndrome - TB/HIV positive SIDA), and 500.000 cases of multidrug resistance (MDR). TB remains corresponding to the magnitude of criteria, transcendence and vulnerability, characterized as a public health problem ${ }^{[3-4]}$.

Studies show that the pattern of occurrence of the disease is related to social determinants. Lately, the situation has worsened as a result of policies adopted, mainly in developing countries, as noted by the increase of new cases and deaths ${ }^{[5]}$. However, as the World Health Organization report in 2013, Brazil was recorded fall in the number of tuberculosis deaths, associated with increased incidence of $\mathrm{TB}^{[6]}$.

Tuberculosis is a re-emerging disease in developed countries, and maintains high prevalence in developing nations. Studies show that there has been a case incidence increasing in these countries and Brazilian states $^{[1]}$. What can justify this situation are the low investment in basic health services, poor housing conditions, poor income distribution and the lack of adequate food in social segments ${ }^{[7-8]}$

Brazil is within the group of 22 countries that together account for $80 \%$ of all TB cases in the world and occupies the $17^{\text {th }}$ position in relation to the number of these cases. In the year 2012 presented incidence coefficient of 72/100.000 inhabitants. The disease presents itself as the fourth leading cause of deaths, infectious disease, and the leading cause of deaths in patients with Acquired Immunodeficiency Syndrome ${ }^{[6]}$.

Remaining as one of the global problems of public health, TB comes to kill about 6000 people per year in Brazil alone. In 1993 the World Health Organization (WHO) in an attempt to control the disease, proposes the nations, to the Directly Observed Treatment Strategy (DOTS), currently known as Directly Observed Treatment (DOT) in order to achieve minimum targets of $85 \%$ cure, $70 \%$ case detection and reduce treatment abandonment by up to $5 \%{ }^{[9-10]}$.

In TB control, as well as other national programs, what we see is that there is a dependency management. Managers need to sensitize up and perform, more efficiently, the actions established by WHO since 1993, as early identification of new cases, rapid intervention in vulnerable groups, proper and early treatment adherence and prevention of death $[7,11]$

Health services must always be in self-assessment. Their goals, philosophies and target groups should be taken into consideration, and thus provide a holistic organization of these. In Brazil, the TB treatment was deployed in the family health strategy, requiring teams, mergers in its activities, and the responsibility for the development of diagnostic actions, treatment and prevention of the disease ${ }^{[12]}$.

It notes the search for the improvement of public health services in Brazil, seeking results as facilitate access to these services and maintain the distribution of anti-tuberculosis drugs, human resources trained/qualified for diagnosis, notification and appropriate follow-up of TB patients ${ }^{[2]}$.

WHO has emphasized that the organizational dimension, along with the performance of health services, is more important than the forms of detection and treatment of TB cases. This thought is understood when one realizes that the DOTS strategy is not simply a clinical approach, but policy for TB control inserted in the health system ${ }^{[12]}$. 
The organization of health services, in accordance with the components of primary health care, requires, among others, the dimensional guaranteed access. And it is through this that one can predict that the evaluation of health services is centered in the relationship needs of the population and the service, its efficiency and effectiveness, in order to produce reliable data to health problems of the population and improve its performance ${ }^{[13]}$.

Therefore, the evaluation of health services under the transdisciplinary perspective, using theories, concepts and tools from various other areas of knowledge, both to indicate effectiveness of an intervention to contribute in making decisions to reorganize the assessed actions ${ }^{[12]}$. Thus, the DOTS follows the guiding focus in decision making and is in the DOT.

The organization of the TB health care services involves providing structural elements, team training, supplies and laboratory network for carrying out diagnostic tests, and providing regular supply of medicines with a view to improve the work process, and the development of individual and institutional, to contribute in facilitating supervised treatment of tuberculosis[10].

In this sense, the study aimed to evaluating the difficulties and facilities in compliance with supervised treatment for tuberculosis from the perspective of managers in controlling tuberculosis in priority cities of the State of Paraiba, the National Tuberculosis Control Programme of the Ministry of Health (NTP/ MS).

\section{Method}

This is an evaluative study of a qualitative approach, the research places were six priority municipalities for the NTP/MS in the State of Paraiba: Joao Pessoa, Bayeux, Santa Rita, Campina Grande, Cajazeiras and Patos.

João Pessoa, the state capital, located in the middle region of the forest area, a population of 723.515 inhabitants, with a population density of 3.421.30 inhabitants $/ \mathrm{km}^{2}$, Human Development Index (HDI) of 0.783 and 0.885 Municipal Human Development Index and Education (IDHM-E). Bayeux, a municipality located in the middle region of the area of the forest, is part of the great João Pessoa, has a population of 90.716 inhabitants, with a population density of 3.118 .76 inhabitants $/ \mathrm{km}^{2}, \mathrm{HDI}$ 0.689 and 0.798 of IDHM-E. Santa Rita, a municipality located in the middle region of the area of the forest, is part of the great João Pessoa, population of 120.310 inhabitants, with a population density of 165.52 inhabitants/km², HDI 0.659 and 0.722 of IDHM-E. Campina Grande, municipality located in the middle region of Borborema, with a population of 385.213 inhabitants, a population density of 648.31 inhabitants $/ \mathrm{km}^{2}$, HDI 0.721 and 0.844 of IDHM-E. Patos, municipality located in the middle region of the Wild, with a population of 100.674 inhabitants, population density of 212.82 inhabitants $/ \mathrm{km}^{2}, \mathrm{HDI}$ 0.678 and 0.768 of IDHM-E. Cajazeiras, municipality located in the middle region of the Wild, with a population of 58.446 inhabitants, population density of 103.28 inhabitants/ km², HDI 0.685 and 0.755 education index - IDHM-E $\mathrm{E}^{[14]}$. Cajazeiras is considered medium-sized and the rest are large.

In this study we were involved six coordinators of TB control actions. To guarantee the confidentiality of those involved, each coordinator symbolically received an abbreviation $\mathrm{E}$ (respondent) and a numerator that ranged from one to six, according to the order in which the interviews were conducted.

Data were collected through semi-structured instrument, applied in the form of recorded interviews, which were later transcribed. They were listed two guiding questions (Which facilities? And what are the difficulties of implementing the DOTS?). We used the analytical technique of Bardin's speech as it sought to understand the ideological position of the discursive subject. When analyzing several speeches about the same theme, it is expected that 
there is agglutination of descriptors that refer to other people's understanding ${ }^{[15]}$. After analyzing the speeches were understood and worked the categories of words (difficulties and facilities).

The research project was approved by the Ethics Committee of the State University of Paraiba, according to Resolution $n^{\circ} 466 / 2012$ of the National Health Council / Ministry of Health, with CAAE $n^{\circ}$ 15221113.6.0000.5187, and Opinion $n^{\circ}$ 311.065. Everyone involved signed the consent form.

\section{Results}

From the subjects involved in the study, five had sensu post-graduation and a higher level course. Regarding training, five attended Nursing and a degree in Education. The average age was 35.6 years old, all female, the average working time exercising coordinating body function was 4 years.

After analyzing the speeches, some key words were taken to facilitate the organization and understanding of the explanation, the words were working condition - for which the trader can play their part; management - the role of managers outside the supervised treatment, lack of commitment - on the part of those involved in the process of supervised treatment; resistance from professionals - in the implementation of supervised treatment; resistance of patients - to adhere to treatment, professionals, key players in therapy; and expansion - Health Strategy for the Family/DOT, agreement signed for search strategy expansion.

\section{Easiness faced by managers}

Within the category easiness there was appointed, by the coordinators of tuberculosis control activities, the acceptability of professionals in the implementation of supervised treatment.

When asked about the patient theme/accession/ treatment/professional, one of the coordinators indicated that its facility was [...] My teamwork, professionals are very reasonable to adhere to treatment directly observed, they make facilities although there resistances of patients (E1).

Within the category easiness and related professional descriptors, other words were identified in the study: drugs, active search and examination, which refers to management, although there are other factors associated with the treatment process, such as the commitment of the management, the fight tuberculosis.

When asked about the matter referred to the interviewee said, [...] As for the acquisition of chemoprophylaxis drugs for tuberculosis, have ease of application and upon arrival; when we thought we'd perform intensified case finding for, we also have facility with the City Department of Health. Another facility would be in reference surveys, the Baars [...] (E2).

In one of the municipalities were identified that offer the benefits of milk has contributed significantly to improve adherence to therapy by patients. However, in another, it was found that patients with TB initially adhered to supervised treatment for the help of the basket. However, they are abandoning the treatment, near the end, in order to begin a new regimen, and thus continue to receive assistance.

Such behavior, assessed as negative in face of TB control, made that municipality to suspend the supply of the food incentive and since then has not offered any advantages. [...] Ease found here in the city for treatment adherence is the own benefit that the city offers! That is milk. We know that TB patients are often unfavorable economically! So this benefits helps, yes. Often the patient does DOT because of this milk. (E5).

For local coordinator, there is awareness on the part of management and who are committed to supervised treatment of tuberculosis. So, to the coordinators of TB control programs, one of the 
facilities found to provide adherence to supervised treatment would be to offer benefit.

Another facility listed for coordinating one of the municipalities that do not offer benefits such as exchange instruments was: [...] The structure of the municipal health, which is almost $100 \%$ coverage family health program, has favored the DOT. (E3).

\section{Difficulties faced by managers}

The lack of working conditions was listed by one of the managers as an obstacle for tuberculosis control and greater effectiveness in the implementation of the directly observed treatment, as shown in excerpt from his speech: [...] In short, is that I do not have conditions work, I have no working conditions [...] (E1).

When asked about the role of management, one of the coordinators expounded [...] But there is a larger issue, the obstacle is that the issue of management, lack of laboratory and materials [...] the last month I had the lack of drugs [...] (E1).

The management needs this different view and greater awareness to put into practice each topic mentioned. Also in relation to management it was quoted that: [...] Management is the gear. To function should be fits all. If not, there is no movement. My biggest difficulty is that it is a look ... a look back the manager to local problems [...] (E1).

Control of TB may not have been regarded as a priority for the local manager or was this just a lack of preparation. Another factor identified as difficulties was the turnover in positions, because they are of a political nature. In the six municipalities there was a change of all municipal health secretaries, due to political elections, and four coordinators of the TB control actions. The talks then prove the fragility, by the management [...] if you have a look of health, will not make health, although there is feature for this, which can be used [...]. If the manager does not have experience, are afraid of lawsuits, it does

\section{[...] because they do not know how to do [...] (E1).}

Another key difficulty identified by managers was the lack of commitment, which allows for greater participation and greatest achievement in the health sector, as evidenced in the following statement: [...] My view on health is the lack of commitment, [...]! We will elaborate a project that benefits our city! Send the Ministry of Health. What is our greatest need? [...] More if neither one nor the other has the initiative to do, there is a commitment (E1).

Another difficulty cited for the consolidation of TB control actions was the resistance of patients. This is noticed in the speeches of the interviewed coordinators: [...] It is difficult to make people aware, the patient, the importance that the medication is for him [...] (E6). Patients reluctant to move from their home to the unit, do not see as easily see how exposure. [...] They were accustomed to the service provided / offered previously. [...] In the previous system, they leave and went to the place of reference for taking medication, they took a lunch and returned home; It was as if no one knew that he had the disease. Already within their area, in their area of residence, which are the health facilities of the family, they think they are more exposed [...]. (E2).

This fact was highlighted in the following words of the interviewees: [...] / believe that the greatest difficulty is the professional's own family health program, has a lot of resistance - with respect to often have to go in the patient's home to observe this treatment. So this is the great difficulty, often they say they will and, in fact, really is not done (E5). [...] They are very troubled, have many activities. So it's difficult to make them understand that the ideal for the patient, is that DOTS is made, that every day go a person in his home, ensure that is the case. [...] I understand how awareness (E6). [...] Some professionals have strength, cannot, not even adhere to TOD proposal; they do not make a bond with the patient, for acceding to TOD. However, there are units that do an excellent job in this regard (E4). 


\section{Discussions}

\section{Easiness}

Although historically have been built to patientprofessional relationship in a vertical way, currently perceives greater sensitivity on the part of the professional. Lately also noticed there be changes in curriculum components of all courses of health graduations in order to train more professionals focused on public health care, and next to this new training, there are better basis on aspects of ethics and humanization.

It is known that to achieve the successful treatment of tuberculosis, is of great importance to understand that first of all, there must be the acceptability of the professional who will give support throughout the treatment process. It is understood that through supervised treatment can keep a management, monitoring and tracking. Policy can be seen at the tip when it shall be exercised in professional practices.

The availability of anti-tuberculosis drugs is one of the pillars of the DOTS, competing for federal, state and municipal levels to manage and provide regular maintenance because, once started the treatment is imperative that the patient be sure to make the taking of drugs daily. Soon, the regular supply can be a guarantee that the patient complies with the appropriate treatment.

A study in Campina Grande municipality pointed out that $91.5 \%$ of the subjects involved in research never ceased to regularly receive their antituberculosis drugs ${ }^{[12]}$, this provision has contributed immensely to an outcome of healing. The regular supply of drugs is fundamental so that the patient does not fail in its proper treatment.

The active search can be understood as the first step in the treatment of tuberculosis, it is through this that one can identify early existing cases of TB, which helps to start the treatment as quickly as possible, contributing to reduce the chain transmission of disease.
The availability of tests for screening and bacteriological diagnosis (smear) becomes essential, so much so that one of the criteria set out in the TB control strategy. Thus, the municipality has to offer this type of service to expedite the closing of the diagnosis of TB.

So that one can achieve success in the treatment of TB cases, the coordinators of the municipalities under study pointed out that, in practice, sometimes there is need for the management offer some encouragement in the form of toast, for patients, for stimulation them in an attempt to foster adherence to supervised treatment.

The benefit is thought in order to offer subsidies to the patient in treatment can provide better response during the same since contemporaneously there are still people living below the poverty line, and they lack the most basic foods ${ }^{[9]}$.

The family health strategy has been presented as the best way of offering health and intervening in the health/community illness. WHO recommends, and the MS incorporated in 2006, the DOT strategy within the agreed goals to be met by the health team, due to the facilities to achieve 100\% population coverage through this pact, and the union of the two strategies. The decentralization of TB control actions for primary care, is justified by better reach good results in supervised treatment, since it favors the bond, the continued care, the active search for cases, control of communicating, as well as facilitate access monitoring the patient for daily taking of medication, since these healthcare facilities are nearby to the user home $e^{[3,16]}$.

\section{Difficulties}

Working conditions involve structural elements related to the worker that affect quality of care. The way to health involves, among other aspects, the physical space itself, which is part of the work as a whole. It needs a space that offers the minimal working conditions with a view to improve the process and develop individual and institutional 
competence ${ }^{[10]}$, unhealthy environments provide dissatisfaction by professionals and users.

It is understood that optimizing and managing resources are part of all actors involved in the treatment of tuberculosis. The role of the manager in the TB approach is fundamental, so that there is greater commitment in the disease control measures.

The qualification of professionals involved in the care of TB management of the necessary inputs and an adequate supply of the laboratory network, so there is continuity and permanence in performing diagnostic tests ${ }^{[10]}$ are of fundamental importance to improve the organization of care provided to the patient and the implementation of the recommended treatment modality for tuberculosis.

Understood that the legalization of the Unified Health System in recent times has grown increasingly due to increased demand for health services, where individual needs have outgrown the collective, and because, most often, because they have ahead of services, managers adapting to new roles in the use of resources may be being misused. The legal support of legalization is guaranteed when the Organic Law of Health (LOS) 8080/90 back in the explanations that health is everyone's right and duty of the State ${ }^{[16]}$, and this, in turn, cannot refrain. Thus, it is understood that the regularity in the distribution of supplies and medicines for tuberculosis has to be maintained regularly, effectively and efficiently, so that if there is a disease control among populations.

A study conducted in Brazil made it clear that a broad strengthening the entire health system is needed, especially with active participation of managers, professionals and the community. There is no thought of combat tuberculosis in mind that the DOTS in its five pillars, together and alone, will solve the problems of that disease ${ }^{[7]}$.

$\mathrm{WHO}$, through the established goals, exposes all spheres of government (Ministry of Health, State and Municipalities) that all should work together, permanently, to strengthen the control policies of tuberculosis and primary health care ${ }^{[10,17-20]}$.

Studies conducted in the State of Paraiba had demonstrated the existence of strong pre-concept by the patient in the process of implementation of supervised treatment (ST), declared in priority municipalities; there were many refusals to patients, adhere to the TS in the Family Health Team in their target areas, but also expressed the desire for treatment in other areas where teams were not in their homes ${ }^{[10,12]}$. However, it is appropriate to emphasize the importance of DOT to guarantee continuity of care and therefore healing ${ }^{[21]}$.

It was also demonstrated resistance from professionals. In services for attention to tuberculosis, which is perceived it is also that, in parallel, there is also strong resistance from professionals in effect the DOT. In a study conducted in São Paulo, access to health services was classified as insufficient, this dimension, inserted in one of the structuring and complex pillars of primary care in health systems $[2,18-20]$.

Resistance to adhere to DOT on the part of professionals and patients, contributes significantly to the control of the disease in the municipalities is no longer effective, and favors, in a way, to maintain the epidemiological situation of the disease, as it focuses significantly the healing of operational indicators and abandonment.

A study involving 134 nations of North America, Asia and Europe showed a significant decrease in TB rates being attributed to large investments in basic services and in health ${ }^{[22]}$.

A positive experience was appointed in Nepal, front ace diversity found in the effectiveness of DOT strategy. The participation of the community and the affected family members in supervised treatment was analyzed, and detected that the involvement of both, it was found that the Community DOTS and DOTS family success rates were $85 \%$ and $89 \%$ in the treatment respectively[23]. Therefore, strategies can be applied in various parts of the world, as part 
of tuberculosis control policy, including Brazil, where studies have shown weaknesses in controlling the disease.

\section{Conclusion}

Managers who work in the development of tuberculosis control actions of municipalities declared priority by the NTCP/MS, Paraiba, Brazil, have faced several problems in all aspects, while they do not recognize facilities to implement the suggested treatment modality WHO/MS.

The DOT strategy has shown good results in countries that have managed to carry out this practice to the health system and should be recognized and encouraged by managers, for professionals, through training and sensitization about the importance of this therapy, and for patients, for through offering social incentives, which can interfere positively, reducing the other difficulties listed by the study subjects.

\section{References}

1. Cunha NV, Cavalcanti MLT, Santos MLF, Araújo VLA, Oliveira e Cruz DM, Pessanha GF, et al. Estrutura, organização e processos de trabalho no controle da tuberculose em municípios do estado do Rio de Janeiro, RJ, Brasil. Interface (Botucatu) [online]. 2014; (14):1-14. doi: 10.1590/1807-57622014.0083

2. Ministério da Saúde (Br). Manual de recomendações para o controle da tuberculose no Brasil [documento on the internet]. 7. ed. Brasilia (DF): Ministério da Saúde; 2012. Available from: http://portal.saude.gov.br/portal/arquivos/pdf/manual_de_ recomendacoes_tb.pdf.

3. World Health Organization. Global tuberculosis control on line [internet]. Geneva; 2011. Available from: http://www.who.int/ tb/publications/global_report/en/index.html.

4. Araújo KMFA, Figueiredo TMRM, Gomes LCF, Pinto ML, Silva TC, Bertolozzi MR. Evolução da distribuição espacial dos casos novos de tuberculose no município de Patos (PB), 2001-2010. Cad saúde coletiva on line [Internet]. 2013 Sept; 21(3): 296-302. doi: http://dx.doi.org/10.1590/S1414-462X2013000300010

5. Sanchez AIM, Bertolozzi MR. Operacionalização do conceito de vulnerabilidade à tuberculose em alunos universitários. Ciênc saúde coletiva on line [Internet]. 2011 Feb; 16(2):669-75. doi:
http://dx.doi.org/10.1590/S1413-81232011000200031

6. Global Tuberculosis Report 2013. The World Health Organization Momitors the Global Tuberculosis Epidemic in Support of National TB Control Programmes. On line [Internet]. Geneva; 2013. Available from: http://apps.who.int/iris/ bitstream/10665/91355/1/9789241564656_eng.pdf

7. Hino P, Cunha TN, Villa TCS, Santos CB. Perfil dos casos novos de tuberculose notificados em Ribeirão Preto (SP) no período de 2000 a 2006. Ciênc saúde coletiva on line [Internet]. 2011; 16(suppl.1): 1295-301. doi http://dx.doi.org/10.1590/S141381232011000700063

8. Secretaria de Estado da Saúde. Divisão de Tuberculose. Centro de Vigilância Epidemiológica Prof. Alexandre Vranjac. Coordenadoria de Controle de Doenças. Mudanças no tratamento da tuberculose. Rev. Saúde Pública on line [internet]. 2010 Feb; 44(1): 197-9. doi http://dx.doi.org/10.1590/S003489102010000100022

9. Secretaria de Estado da Saúde. Instituto Clemente Ferreira, Coordenadoria de Controle de Doenças. Desafios da tuberculose diante da resistência microbiana. Rev. Saúde Pública on line [Internet]. 2011 Oct; 45(5): 997-1000. doi: http://dx.doi. org/10.1590/S0034-89102011000500025

10. Sá LD, Andrade MN, Nogueira JA, Villa TCS, Figueiredo TMRM, Queiroga RPF, et al. Implantação da estratégia DOTS no controle da Tuberculose na Paraíba: entre o compromisso político e o envolvimento das equipes do programa saúde da família (1999-2004). Ciênc saúde coletiva on line [internet]. 2011 Sept; 16(9):3917-924. doi: http://dx.doi.org/10.1590/S141381232011001000028

11. Sá LD, Oliveira AAV, Souza KMJ, Palha PF, Nogueira JA. Villa TSC. Early treatment and cast services in the care of tuberculosis patient. Rev Enferm UFPE on line [internet]. 2010; 4(3):1515-22. doi: 10.5205/01012007

12. Figueiredo TMRM, Villa TCS, Scatena LM, Gonzales RIC, Ruffino-Netto A, Nogueira JA, et al. Desempenho da atenção básica no controle da tuberculose. Rev Saúde Pública. 2009 Sept; 43(5): 825-31. doi: http://dx.doi.org/10.1590/S003489102009005000054

13. Tanaka OY, Tamaki EM. O papel da avaliação para a tomada de decisão na gestão de serviços de saúde. Ciênc. saúde coletiva on line [Internet]. Rio de Janeiro, 2012 Apr; 17(4): 821-8. doi: http://dx.doi.org/10.1590/\$1413-81232012000400002

14. Instituto Brasileiro de Geografia e Estatística (IBGE). Censo demográfico: resultados definitivos, municípios da Paraíba, 2000 e 2010. On line [internet]. Available from: http://censo2010.ibge. gov.br/

15. Bardin L. Análise de conteúdo. 4 ed. Lisboa: Edições 70, LTDA; 2000.

16. Ministério da Saúde (BR). Programa Nacional de Controle da Tuberculose. Situação da Tuberculose no Brasil. On line [internet]. 2012. Available from: http://portal.saude.gov.br/ portal/ arquivos/pdf/AP. 
17. World Health Organization. Global tuberculosis report 2012 [document on the internet]. Geneva: World Health Organization; 2012. Available from: http://www.who.int/tb/publications/ global_repor t/en/index.html.

18. Viacava F, Ugá MAD, Porto S, Laguardia J, Moreira RS. Avaliação de Desempenho de Sistemas de Saúde: um modelo de análise. Ciênc. saúde coletiva online [Internet]. 2012 Apr; 17(4): 921-34. doi: http://dx.doi.org/10.1590/S1413-81232012000400014

19. Alves RS, Souza KMJ, Oliveira AAV, Palha PF, Nogueira JA, Sá LD. Abandono do tratamento da tuberculose e integralidade da atenção na estratégia saúde da família. Texto Contexto Enferm., Florianópolis, 2012; 21(3): 650-7. doi: http://dx.doi.org/10.1590/ S0104-07072012000300021

20. Santos MLSG, Villa TCS, Vendramini SHF, Gonzales RIC, Palha PF, Santos NSGM, et al. A gerência das ações de controle da tuberculose em municípios prioritários do interior paulista. Texto Contexto Enferm., Florianópolis, 2010 Jan-Mar; 19(1): 64-9. doi http://dx.doi.org/10.1590/S0104-07072010000100007

21. Lacerda SNB, Temoteo RCA, Figueiredo TMRM, Luna FSTL, Sousa MNAS, Abreu LC, et al. Individual and social vulnerabilities upon acquiring tuberculosis: a literature systematics review. Internacional Arquives of Medicine, 2014 July; 7(35): 1-8. doi: 10.1186/1755-7682-7-35. PMCID: PMC4110238.

22. Dye $C$, Lonnroth $K$, Jaramillo $E$, Williams BG, Raviglione $M$. Trends in tuberculosis incidence and their determinants in 134 countries. Bull World Health Organ online [Internet]. 2009; 87(9): 683-91. doi:10.2471/BLT.08.058453

23. Newell JN, Baral SC, Pande SB, Bam DS, Malla P. Family-member DOTS and community DOTS for tuberculosis control in Nepal: cluster-randomised controlled trial. The Lancet, 2006 Mar; 367(9514): 903-09. DOI: http://dx.doi.org/10.1016/S01406736(06)68380-3

\section{Comment on this article:}

\section{(f) $B$ in $8+\boldsymbol{S} P$}

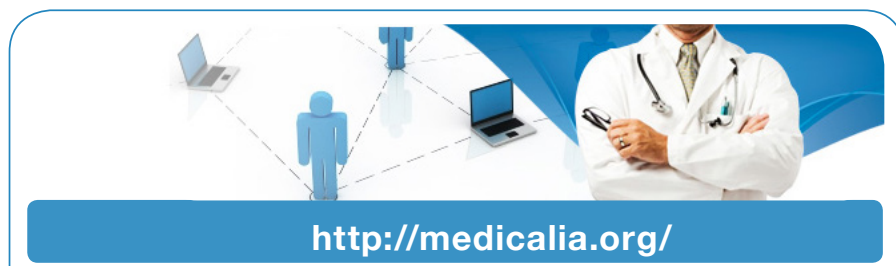

Where Doctors exchange clinical experiences, review their cases and share clinical knowledge. You can also access lots of medical publications for free. Join Now!

\section{Publish with iMedPub}

\section{http://www.imed.pub}

International Archives of Medicine is an open access journal publishing articles encompassing all aspects of medical science and clinical practice. IAM is considered a megajournal with independent sections on all areas of medicine. IAM is a really international journal with authors and board members from all around the world. The journal is widely indexed and classified Q1 in category Medicine. 